LETTER 19

\title{
PETER THE VENERABLE: AN EPITAPH FOR ABELARD
}

The Socrates of the Gauls, the greatest Plato of the West, our Aristotle, Peer or superior to all other logicians, whoever they may be,

Acknowledged prince of worldly studies, subtle, sharp, and diverse in the range of his talents,

Best of all in the force of reason and the art of speaking was Abelard.

But with far greater distinction as a professed monk of Cluny,

He passed over to the philosophy of Christ. Through his long striving,

At the end of his life, he won hope of a place with God's philosophers. 